\title{
Development and testing of new performance measures for milksolids production per hectare
}

\author{
C.B. GLASSEY \\ Dexcel, Private Bag 3221, Hamilton \\ chris.glassey@dexcel.co.nz
}

\begin{abstract}
With increased use of feed from outside the effective milking area on dairy farms, milksolids (MS) per effective ha is no longer a sound basis for comparing farms and evaluating options for improving efficiency and profitability. Development of new, quantitative measures for feed and land use efficiency is required. These measures should take account of the extra land used to grow all feed types used for MS production and define how well the feed grown and purchased is converted into MS. Two methods were used to re-calculate MS per ha for six high performing farms (average of $2073 \mathrm{~kg}$ MS per effective ha) using a wide range of imported feed. Using these calculations, the farms averaged 1513 $\mathrm{kg}$ MS per total ha used and $1450 \mathrm{~kg}$ MS per ha produced from home grown pasture and crops. Yields of home grown pasture and crop harvested per effective ha ranged from 14.7 to $17.5 \mathrm{t} \mathrm{DM}$ per ha and feed conversion efficiency ranged from $85-94 \mathrm{~kg}$ MS per tonne DM. These benchmarks can be used to identify opportunities to improve pasture grown, harvested and converted into milksolids on NZ dairy farms.
\end{abstract}

Keywords: milksolids per hectare, imported feed, pasture harvested per ha, feed conversion efficiency

\section{Introduction}

Sustainable, profitable dairying in New Zealand depends on maximising the efficiencies with which pasture is grown, harvested and converted into milk by grazing cows.

New Zealand dairy farmers are increasingly reliant on feed from outside the effective milking area of their farms (effective milking area $=$ total farm area less that area that cannot be grazed) (DairyBase Reference Manual 2006). Unpublished data from Dexcel's Economic Survey of New Zealand Dairy Farmers show that from 1997 to 2005 the amount of feed brought in from outside the effective milking area increased from 0.64 tonnes dry matter per ha (t DM/ha) to $1.47 \mathrm{t} \mathrm{DM} / \mathrm{ha}$, a rate of +0.10 $\mathrm{t} \mathrm{DM} / \mathrm{ha}$ per year.

The amount and cost of imported feed and how effectively it is used can create large differences in the financial and physical performance of farms. These are not reflected by comparing MS production per effective milking hectare. In research farmlet comparisons, increased amounts of feed imported from outside the effective milking area increased MS production per ha but did not always increase profitability (Jensen et al. 2005; Macdonald 1999). In a study of 626 commercial $\mathrm{NZ}$ dairy farms, farmers using large amounts of imported feed produced more MS per ha compared to farms using lower amounts or no imported feed, but there were no differences in profitability between groups (SilvaVillacorta et al. 2005).

Importing feed on to dairy farms can improve profitability of dairy farming where it drives increases in pasture harvested per ha, is well managed and the costs of feeding are contained (Hedley et al. 2006). Importing feed also increases the resource use of land, fuel and fertiliser and therefore the environmental footprint of dairying. Unpublished data from Dexcel's Economic Survey shows that for every 1 ha of milking land in the Waikato another 0.3 ha of land is used to support production.

Dexcel's Resource Efficient Dairying trial (Jensen et al. 2005) highlighted how additional land and feed resources supporting a high feed-input farm system alters the system's financial viability and environmental impact. The efficiency with which all resources are used needs to be measured and compared to a low input system or an industry standard. Profitability measures provide one indicator of efficiency but this is not based on total land and feed resource use from the biological and environmental view. For this reason, testing and developing new measures that count all the hectares used for supplying feed for MS production on dairy farms is underway. In addition, there is a need to benchmark the highest levels of current annual energy and DM yield of pastures and forages in relation to progress towards dairy industry research targets (Anon. 2005).

\section{Methods}

To account for additional hectares supplying feed, two methods of re-calculating MS/ha were compared for six high performing dairy farms representing a wide range in the quantity of feed imported. In addition, a farmlet has been established with the aim of identifying the limit for how many MS can be produced from feed grown on a set area, without importing feed. These two methods have been developed and trialled for use by farmers and consultants. 
Table 1 Example of milk solids/total ha used, calculated for a 100 effective ha farm producing 150,000 kg milksolids/ha (1500 kg milksolids/effective ha).

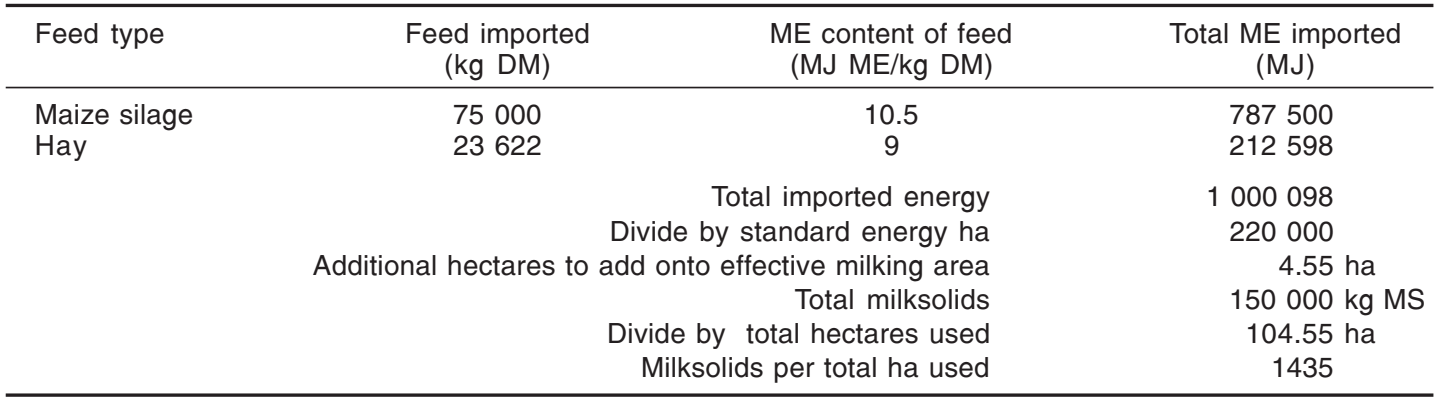

\section{Method A: Milksolids per total ha used}

This is calculated as follows:

Step One: Estimating annual feed energy imported to the farm using the weight of feed imported in DM and converting to metabolisable energy (MJME) either using known (measured) energy content or standard energy values for each type of feed (Dexcel Farm fact.5-1, www.dexcel.co.nz).

Step Two: Total annual feed energy imported is divided by a standard energy hectare. The standard proposed represents 1 ha growing 21 tonne DM of maize silage of $10.5 \mathrm{MJ} \mathrm{ME} / \mathrm{kg} \mathrm{DM}$ or 220,000 MJ ME/ha.

An example of this calculation can be found in Table 1 .

\section{Method B: Milksolids per ha equivalent from home grown feed}

This can be calculated as follows:

Step One: Calculation of total pasture and crop energy eaten is calculated as $M J M E / h a$, and total $\mathrm{kg} D M$ eaten/ha.

An estimate of the annual energy requirements to support a level of milksolids production per effective ha can be completed using standard energy equations. Calculators to assist this process are available on the internet; e.g. from Massey University at http:// www.dairy3.org.nz/page.php?9

Similar calculations are performed for a farm supplying level two physical data to DairyBase (DairyBase Reference Manual 2006) and are based on the following; Total Energy Eaten (MJ) calculated from energy used per cow for:

Milksolids - Annual milksolids production ( $\mathrm{kg}$ )

Maintenance

Processing low/high quality feed and the cost of grazing Pregnancy

Walking

Multiply by stocking rate (cows per effective milking ha) = Total energy eaten MJ ME/ha

Divide this figure by the average MJ ME/kg DM of the pasture and supplements over the year.

$=$ Total tonnes $\mathrm{DM}$ eaten $/ \mathrm{ha}$

Step Two: Calculate energy eaten from home grown feed MJME/ha

Total energy eaten/ha

Less energy eaten from imported supplements

$\mathrm{kg}$ DM supplements per ha $\mathrm{x}$ Utilisation $\mathrm{x}$ Quality $\mathrm{MJ} \mathrm{ME} / \mathrm{kg} \mathrm{DM}$

$=$ Energy eaten $/$ ha from home grown feed

Step Three: Calculation of tonnes of dry matter eaten/ha from home grown feed

Energy eaten (MJ ME/ha) from home grown feed (Step Two) divided by the average quality of the pasture and crop (MJ ME/kg DM, either the standard values or measured values if known).

= Tonnes DM eaten/ha from home grown feed.

Step Four: Calculation of $\mathrm{kg}$ DM eaten $/ \mathrm{kg}$ MS

Total tonnes of dry matter eaten/ha (from Step One)

Divided by MS per effective milking ha.

$=\mathrm{kg}$ DM eaten per $\mathrm{kg} \mathrm{MS}$

Step Five: Calculation of MS/ha from home grown pasture and crop eaten

(Tonnes home grown DM eaten $/ \mathrm{ha}$ )

$(\mathrm{kg}$ DM eaten $/ \mathrm{kg} \mathrm{MS}) \times 1000$

$=\mathrm{MS} / \mathrm{ha}$ from home grown pasture $/ \mathrm{crop}$

Example:

Step 1: Herd of $490 \mathrm{~kg}$ cows, producing $483 \mathrm{~kg}$ milksolids requires $56380 \mathrm{MJ} \mathrm{ME} / \mathrm{cow} / \mathrm{yr}$. For a farm stocked at $3.6 \mathrm{cows} / \mathrm{ha}$ this is $202968 \mathrm{MJ} \mathrm{ME/}$ ha.

At an average ME of $11.7 \mathrm{MJ} / \mathrm{kg} \mathrm{DM}$ this equates to $17348 \mathrm{~kg} \mathrm{DM} / \mathrm{ha}$.

Step 2:1000 kg DM per cow is imported in the form of maize silage at $10.5 \mathrm{MJ} \mathrm{ME} / \mathrm{kg} \mathrm{DM}=10500 \mathrm{MJ} \mathrm{ME} /$ cow $\mathrm{x} 80 \%$ utilisation $\mathrm{x} 3.6$ cows per ha $=30240 \mathrm{MJ}$ 
$\mathrm{ME} / \mathrm{ha}$.

Energy eaten from home grown feed is 202968 - 30 $240=172728 \mathrm{MJME} / \mathrm{ha}$.

Step 3: Pasture is 11.9 MJ ME/kg DM and maize silage $10.5 \mathrm{MJ} \mathrm{ME} / \mathrm{kg} \mathrm{DM}$

Home grown pasture $=172728 \mathrm{MJ}$ ME/11.9 $=14515$ $\mathrm{kg} \mathrm{DM} / \mathrm{ha}$

Maize $=30240 \mathrm{MJ}$ ME $/ 10.5=2880 \mathrm{~kg} \mathrm{DM} / \mathrm{ha}$

Total DM eaten $=17395 \mathrm{~kg} \mathrm{DM} / \mathrm{ha}$.

Average ME eaten $=202968 \mathrm{MJ}$ ME$/ 17395=11.7 \mathrm{MJ}$ $\mathrm{ME}$

Step 4:

$17395 \mathrm{~kg}$ DM produces $1738 \mathrm{~kg} \mathrm{MS} / \mathrm{ha}$ (3.6 cows/ ha. $x 483 \mathrm{~kg} \mathrm{MS} / \mathrm{cow})=10.0 \mathrm{~kg} \mathrm{DM} / \mathrm{kg} \mathrm{MS}$

Step 5: $\underline{\text { Total home grown feed eaten }}=\underline{14515}$ $\mathrm{kg}$ DM eaten per kg MS 10

$=1451 \mathrm{~kg} \mathrm{MS} /$ ha produced from home grown feed

Using the above methods a comparison between six different high performing farm systems was completed.
These farms include two high performing commercial Waikato dairy farms (Farms 1 \& 2), Lincoln University Dairy Farm (Farm 3) and three Dexcel farmlets, Super Productivity Farmlet, RED Trial Treatment E and the Strain Trial (Farms $4-6$ respectively) (Table 2 ).

\section{Establishment of a prototype "Super Productivity"} farmlet:

In June 2006, a farmlet of 8 ha with 29 cows was established at Dexcel's Scott Farm near Hamilton. This project aims to determine how the boundaries to sustainable and productive dairy farming can be moved. Specifically, this is to increase the production of milksolids/total ha used by $20 \%$ to $1750 \mathrm{~kg} \mathrm{MS} /$ total ha. This addresses the improvement required in the amount of feed energy grown from a defined area and having that converted into MS. All feed that contributes to this production must be grown within the farmlet boundaries.

The performance will be benchmarked against leading commercial farms on an annual basis in relation to MS production/total ha used, net herbage accumulation, pasture eaten, pasture and forage crop energy eaten, and economic farm surplus/ha.

Table 2 A comparison milksolids/total ha used for six dairy farm systems with imported feed energy converted to standard additional hectares (Method A).

\begin{tabular}{lcccccc}
\hline & Farm 1 & Farm 2 & Farm 3 & Farm 4 & Farm 5 & Farm 6 \\
\hline MS/effective milking ha & 2460 & 2948 & 1772 & 1480 & 2230 & 1549 \\
Estimated GJ ME/ha imported feed & 105.5 & 202.9 & 31.2 & 0 & 133.6 & 15.1 \\
$\quad \begin{array}{l}\text { Additional standard ha. as \% of } \\
\text { effective milking ha }\end{array}$ & $47 \%$ & $92 \%$ & $14 \%$ & 0 & $60 \%$ & $7 \%$ \\
MS/total ha used & 1677 & 1533 & 1552 & 1480 & 1388 & 1448 \\
\hline $\begin{array}{l}1 \\
\text { Jensen et al. 2005 }\end{array}$ & & & & & & \\
\hline
\end{tabular}

Figure 1 A comparison of milksolids/effective ha, milksolids/total ha and milksolids/ha from home grown feed for six high performing farms.

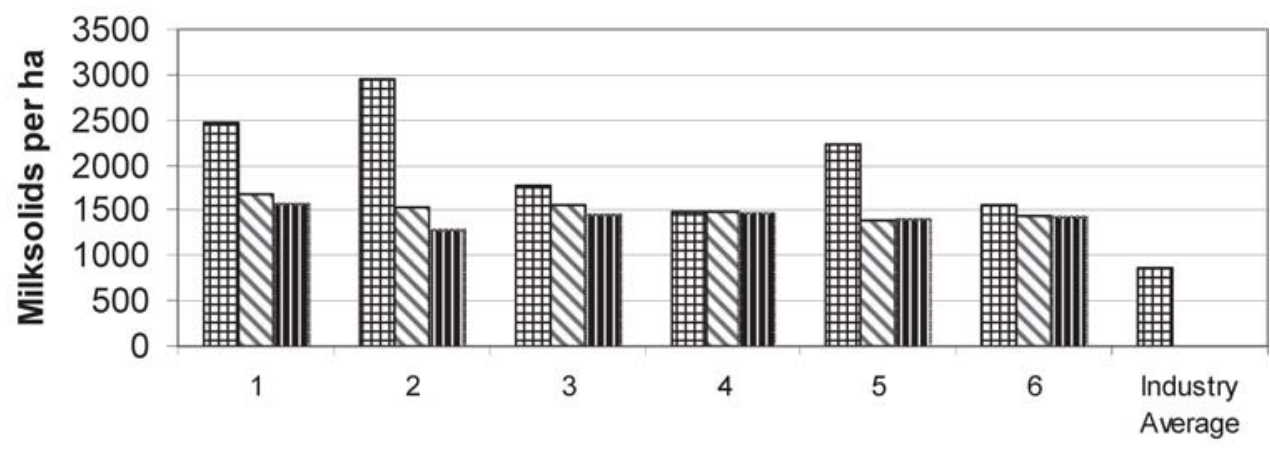

Farm 


\section{Results and Discussion}

\section{Method A: Comparing MS per total ha used with MS/effective milking ha}

The production of the six selected farms ranged from 1480 to $2948 \mathrm{~kg}$ MS/effective ha compared with the industry average of $862 \mathrm{~kg} \mathrm{MS} / \mathrm{ha}$. After calculating MS/ total ha used the range was reduced to 1388 to $1677 \mathrm{~kg}$ MS/total ha used (Table 2 and Fig. 1)

\section{Method B: Calculating MS per ha equivalent from home grown feed}

A comparison of the same six farms using Method B produced a range from 1299 to $1589 \mathrm{~kg} \mathrm{MS} / \mathrm{ha}$ from home grown feed and resulted in some re-ranking of the farms (Table 3). With Method B, estimates of MS production were on average $63 \mathrm{~kg} \mathrm{MS} /$ ha lower than using Method A. Method B includes an estimate of the pasture and crop harvested inside the effective milking area and this increases the sensitivity of the measure where larger amounts of imported feed have been used to generate more MS. The standardised hectares method (Method A) uses an estimate of the total energy in DM offered to the herd and the area involved in supplying that feed using a standard yield per ha for all farms. Method B takes into account the efficiency with which supplement is used to produce milksolids on each individual farm. This efficiency is influenced by quality and utilisation of the supplement, and how well this supplement is integrated with the pasture harvested.

The farm where the ranking shifted the most was farm 2, a farm with the highest total feed supply, the highest proportion of imported feed and the most varied types of supplementary feed. The more self-contained a farm is in relation to feed supply, the easier it is to estimate total land resource use because there are fewer steps and less estimates.

\section{Prototype farm}

The prototype farm (Farm 4) provides a benchmark because all feed is produced in a known area and is of similar type which reduces the number of assumptions used for feed utilisation and feed quality. In its first season of operation the prototype farm achieved $1480 \mathrm{~kg} \mathrm{MS} /$ total ha from an estimated 16.4 tonne $\mathrm{DM} / \mathrm{ha}$ eaten. This is $15 \%$ short of the target production of $1750 \mathrm{~kg}$ MS per ha.

\section{Achieving $1750 \mathrm{~kg}$ MS/total ha used}

The comparisons demonstrated that leading NZ dairy farms are currently producing at a level of just over 1500 $\mathrm{kg} \mathrm{MS} /$ total ha used. To achieve this, they are strategically using feeds brought in from outside the dairy farm to obtain a pasture and forage consumption approaching $200 \mathrm{GJ}$ ME/ha (Table 4) and are converting feed to milk production at $85-95 \mathrm{~kg} \mathrm{MS} / \mathrm{t} \mathrm{DM}$. The DM harvested from the milking area for the highest $\mathrm{MS} / \mathrm{ha}$ farm is estimated at $17.5 \mathrm{t} \mathrm{DM} / \mathrm{ha}$ (using Dexcel's Profit Doctor). To achieve $1750 \mathrm{~kg} \mathrm{MS} /$ total ha used at the current level of feed conversion efficiency for this farm $(91 \mathrm{~kg} \mathrm{MS} / \mathrm{t}$ DM, Table 4), on average 19.5 tonnes DM/ha (i.e. an additional 1.7 tonnes DM/ha) would need to be harvested. Assuming this extra feed contains $11.5 \mathrm{MJ} \mathrm{ME} / \mathrm{kg} \mathrm{DM}$, this is an additional $19.5 \mathrm{GJ} \mathrm{ME} / \mathrm{ha}$ (a total of $220 \mathrm{GJ}$ $\mathrm{ME} / \mathrm{ha}$ ). Assuming that the current rate of utilisation of the feed is $75 \%$ of what is currently grown (Macdonald et al. 2001), then current DM grown on this farm is likely to be $23.3 \mathrm{t} / \mathrm{ha}$. If there were no gains in feed utilisation, then increasing the DM grown to $25 \mathrm{t} \mathrm{DM} / \mathrm{ha}$ is required. Alternatively an increase in feed utilisation to $82 \%$ of current feed grown would capture the extra feed required to achieve $1750 \mathrm{~kg} \mathrm{MS} / \mathrm{ha}$, as would an improvement in feed conversion efficiency to $100 \mathrm{~kg}$ MS/t DM.

Table 3 A comparison of milksolids/ha for six farms using two methods for accounting for additional land used for supplying feed.

\begin{tabular}{lccccccc}
\hline & Farm 1 & Farm 2 & Farm 3 & Farm 4 & Farm 5 & Farm 6 & Mean \\
\hline Method A & 1677 & 1533 & 1552 & 1480 & 1388 & 1448 & 1513 \\
Ranking & 1 & 3 & 2 & 4 & 6 & 5 & \\
Method B & 1589 & 1299 & 1467 & 1480 & 1420 & 1443 & 1450 \\
Ranking & 1 & 6 & 3 & 2 & 5 & 4 & \\
\hline
\end{tabular}

Table 4 Estimates of feed eaten (t DM/ha), feed conversion efficiency (kg MS/t DM) and home grown energy eaten (GJ ME/ha) for six farms.

\begin{tabular}{lccccccc}
\hline & Farm 1 & Farm 2 & Farm 3 & Farm 4 & Farm 5 & Farm 6 & Industry \\
& 1 & 2 & 3 & 4 & 5 & average \\
\hline Feed eaten & 27.1 & 33.4 & 19.6 & 16.4 & 26.2 & 16.42 & 12.2 \\
Feed conversion & 91 & 88 & 90.4 & 89.7 & 85 & 94 & 77 \\
Home grown energy eaten & 201.1 & 169 & 197 & 186 & 195 & 179 & Not calculated \\
\hline
\end{tabular}

${ }^{1}$ W. Montgomerie pers. comm. 


\section{Conclusion}

The quickest and easiest method of recalculating MS/ effective ha to a value that provides a better indicator of resource use is Method A. While there is reasonable agreement between the two methods, the use of standardised hectares in Method A may not reflect efficiencies gained by individual farms. Method B is more farm specific and requires more complex calculations for each farm. It is likely that farmers will struggle to collect and use the data for this calculation themselves although inputs for this calculation can be produced for them from DairyBase. (DairyBase Reference Manual 2006). Encouraging farmers to assess farm performance beyond MS/effective ha will allow identification of opportunities to improve pasture grown, harvested and converted into milksolids. It will also allow researchers to identify opportunities and monitor progress against industry research targets for feed use on farms.

\section{ACKNOWLEDGEMENTS}

To the two farmers who willingly supplied data for the comparison and to Phillipa Hedley of Dexcel for her ideas on use of the DairyBase output.

\section{REFERENCES}

Anon. 2005. Strategic Framework for Dairy Farming's Future 2005-2015, Dairy Insight.

DairyBase Reference Manual, 2006. Dairy Insight.
Hedley, P.; Kolver, E.; Glassey,C; Thorrold, B.; van Bysterveldt, A.; Roche, J.; Macdonald, K. 2006. Achieving high performance from a range of farm systems. p 147. In: Proceedings of the 4th Dairy 3 Conference.

Jensen, R.N.; Clark, D.A.; Macdonald, K.A. 2005. Resource Efficient Dairying trial: measurement criteria for farm systems over a range of resource use. Proceedings of the New Zealand Grassland Association 67: 47-52.

Macdonald, K.A. 1999. Determining how to make inputs increase your economic farm surplus. pp 78-87. In: Proceedings of the 51st Ruakura Farmers Conference.

Macdonald, K.A.; Thorrold, B.; Pryce, J. 2005. Dexcel Holstein-Friesian Strain Trial-Are all Black and Whites created equally? p 165. In: Proceedings of the 3rd Dairy 3 Conference.

Macdonald, K.A.; Penno, J.W.; Nicholas, P.K.; Lile, J.A; Coulter, M.; Lancaster, J.A.S. 2001. Farm systems - impact of stocking rate on dairy farm efficiency. Proceedings of the New Zealand Grassland Association 63: 223-227.

Silva-Villacorta, D.; Holmes, C.W.; Shadbolt, N.M; Lopez-Villalobos, N; Prewer, W.; Glassey , C.B.; Blackwell, M. 2005. The productivity of pasture-based dairy farms in New Zealand with different levels of extra feed input. Proceedings of the New Zealand Society of Animal Production 65: 63-67. 